\title{
BAIT AL-HIKMAH DAN KONTRIBUSINYA DALAM PERKEMBANGAN TRADISI KEILMUAN ISLAM PADA ERA ABBASIYAH
}

\author{
Salahudin \\ STAIN Datokarama Palu, Jl. Diponegoro No. 23 Palu \\ E-mail: salahuddin@yahoo.com
}

\begin{abstract}
Abstrak: Periode kekuasaan Dinasti Abbasiyah sering disebut sebagai zaman keemasan Islam. Disebut demikian karena pada masa ini, telah muncul berbagai ilmuan muslim di berbagai bidang, seperti hokum Islam dan filsafat. Kemunculan para ilmuan Islam pada masa ini tentu saja berkaitan erat dengan perintah menuntut ilmu pengetahuan dalam Islam dan dukungan para khalifah pada saat itu. Karena perintah menuntut ilmu ini pulalah, pada masa ini telah didirikan Bait al-Hikmah, sebuah lembaga penerjemahan karya-karya Yunani ke dalam bahasa Arab. Karya-karya terjemahan yang telah disempurnakan dengan pemikiran baru para penterjemah ahli kemudian dibukukan dan disebarkan ke Eropa melalu Syria, Spanyol (Andalusia) dan Sicilia. Itulah yang menjadi basis yang dominan dalam perkembangan ilmu pengetahuan di Barat yang terjadi sejak awal era Renaisans. Bahkan karya-karya itulah yang mendorong terjadinya era Renaisans di Barat.
\end{abstract}

Abstract: The Period of Abbasid rule was also called the golden age of Islam. It was so called since in that period, some Muslim scholars in the field of Islamic law and philosophy emerged. The emergence of Muslim scholars at that time was closely related to the obligation to search knowledge in Islam and the supports of the caliphs. It is because of the obligation that a translation institution called Bait al-Hikmah was established. In this institution, the Greek works were translated into Arabic. The translation works were then completed with new thoughts of the translators and spread out to Syria, Spain and Cecilia. It was the dominant basis for the development of science in the West since the beginning of the Renaissance era.

Kata Kunci: Bait al-Hikmah, tradisi keilmuan Islam, era Abbasiyah 


\section{PENDAHULUAN}

Penciptaan manusia disertai dengan berbagai potensi, yang dapat membuatnya menjadi makhluk yang berbudaya ${ }^{1}$ dalam interaksinya dengan lingkungannya. Agama bagi manusia adalah antara lain pada dasarnya untuk membantu dalam perjalanannya menunju martabat makhluk berbudaya sesuai dengan citra penciptaannya itu. $^{2}$

Dalam kerangka tersebut dapat dipahami bahwa hal pertama yang diharuskan dalam Islam yang dibawa rasul-Nya Muhammad saw. adalah berkenaan dengan jalan menuju keberbudayaan yaitu membaca. ${ }^{3}$ Hasilnya, segera setelah Islam datang, masyarakat yang disentuhnya terbawa kepada tingkat keberbudayaan yang mengagumkan dan menjadi pusat perhatian dunia. Nourouzzaman Shiddiqi memberikan ilustrasi bahwa:

Sejak abad I H./VII M. sampai dengan abad IV/X M. pusat perkembangan kebudayaan dan peradaban dunia berada di Baghdad, Cordova dan Kairo. Ke kota-kota inilah para cendekiawan datang untuk belajar atau berkonsultasi. Baghdad, Cordova dan Kairo adalah ibukotaibukota kekhalifahan muslim. Baghdad adalah tempat kedudukan

${ }^{1}$ Kebudayaan diambil dari kata budaya: pikiran, akal budi atau sesuatu mengenai kebudayaan. Kebudayaan : Hasil kegiatan dan penciptaan batin manusia. Berbudaya berarti: mempunyai budaya; mempunyai pikiran dan akal yang sudah maju. Depdikbud, Kamus Bahasa Indonesia (Edisi II; Jakarta: Balai Pustaka, t.th.), h. 149. Kebudayaan ialah Suatu sikap batin, sifat dari jiwa manusia; usahanya untuk mempertahankan hakikat dan kebebasannya sebagai makhluk yang mulia. Lihat: Nourouzaaman Shiddiqi, Pengantar Sejarah Muslim (cet. Ke-1; t.tp. : Nur Cahnya, 1983), h. 6.

${ }^{2}$ Hal tersebut antara lain dapat ditangkap dari pemahaman terhadap Q.S. al-Tīn (95): 4 "sesungguhnya Kami telah menciptakan manusia dalam sebaikbaik kejadian". Al Qur'an dan Terjemahannya (Madīnah al-Munawwarah: t.p., 1412 H.), h. 1076.

${ }^{3}$ Wahyu pertama yang diterima Rasulullah saw. adalah Q.S. al-'Alaq (96): 1-5. Wahyu tersebut tidak menjelaskan apa yang harus dibaca karena Alquran menghendaki umatnya membaca apa saja selama bacaan tersebut "bismi robbik", dalam arti bermanfaat untuk kemanusiaan. "Iqra" berarti bacalah, telitilah, dalamilah, ketahuilah ciri-ciri sesuatu, bacalah alam, tanda-tanda zaman, sejarah, maupun diri sendiri, yang tertulis maupun tidak. Lihat, M. Quraish Shihab, Wawasan Al-Qur'an (cet. ke-3; Bandung: Mizan, 1996), h. 433. 
Dinasti Abbasiyah. Cordova ibukota Dinasti Umaiyyah Barat dan Kairo ibukota Dinasti Fațimiyyah. Baghdad, Cordova dan Kairo bisa berfungsi dan berperan sebagai pusat-pusat pengkajian ilmu pengetahuan kerena para khalifah dan sarjana-sarjana muslim adalah pencinta-pencinta ilmu pengetahuan. Mereka tidak memusuhi ilmu pengetahuan bahkan berpendapat mempelajari ilmu pengetahuan adalah salah satu dari perintah agama juga. ${ }^{4}$

Kutipan tersebut antara lain menunjukkan bahwa tingkat kemajuan kebudayaan yang dicapai kaum muslim yang begitu pesat sejak awal perkembangannya, secara historis dapat dipandang tidak terlepas dari faktor teologis nilai-nilai ajaran yang diyakininya sehingga memotivasi dan mendinamisir langkah-langkah pencarian ilmu pengetahuan. Hal lain yang dapat dipahami dari kutipan tersebut adalah bahwa tingkat kemajuan itu telah beragam. $^{5}$

Secara khusus, dalam bidang pencapaian perkembangan ilmu pengetahuan, para sejarawan biasanya membedakan atau membuat klasifikasi keilmuan itu ke dalam pertama, kelompok ilmu pengetahuan yang berhubungan dengan Alquran disebut ilmu pengetahuan asli (native sciences) yang meliputi ilmu-ilmu keagamaan atau al-'Ulūm al-Naqliyyah atau al-Syarīah, dan kedua, kelompok ilmu pengetahuan asing (foreign sciences) yang

${ }^{4}$ Shiddiqi, Tamaddun Muslim (cet. ke-1; Jakarta: Bulan Bintang, 1986), h. 19. Dalam kesempatan lain Nourouzzaman Shiddiqi juga pernah menyatakan bahwa motif mereka (cendekiawan muslim di sekitar masa awal periode Abbasiyah) mengkaji ilmu pengetahuan, khususnya filsafat, astronomi, kedokteran dan sejarah adalah untuk dapat menjelaskan keberadaan Tuhan. Kegiatan mereka mengkaji ilmu pengetahuan ini berangkat dari firman Tuhan yang memerintahkan agar manusia mengkaji jagat raya dan diri mereka sendiri (Q.S. Fushshilat (41):53; Q.S. Yunus (10):101) sebab kesemuanya itu adalah bagian dari tanda-tanda (ayat) keberadaan Tuhan. Lihat Nourouzzaman Shiddiqi, Jeram-Jeram Peberadaban Muslim (cet. ke-1; Yogyakarta: Pustaka Pelajar, 1996), h. 33-4.

${ }^{5}$ Tingkat keragaman "capaian” kaum Muslim dimaksud, lebih lanjut dapat dibaca dalam Shiddiqi, "tamaddun...”, ibid., h. 19-65 
meliputi filsafat (al-'Ulūm al-Aqliyyah) yang biasa pula disebut sebagai ilmu kuno (al-'Ulūm al-Qadìmah). ${ }^{6}$

Berhasilnya pencapaian kemajuan di bidang kebudayaan, khususnya ilmu pengetahuan yang demikian pesat dan beragam itu adalah berkat dorongan internal (faktor teologis) dan faktor eksternal yang antara lain berupa sentuhan dengan peradaban dan budaya luar yang berupa kontak intelektual dengan filsafat dan budaya Yunani pada masa itu. Persentuhan antar kebudayaan dimaksud sebenarnya sudah berlangsung sejak masa umaiyah, $^{7}$ namun kemudian mencapai puncaknya pada era Abbasiyah berkat terlembagakannya upaya-upaya penterjemahan, yang kemudian dikenal dengan nama Khizāna alHikmah maupun Bait al-Hikmah .

Dalam tulisan ini akan dibahas: (1) motivasi didirikannya Bait al H\{ikmah; (2) keberadaan Bait al-Hikmah; dan (3) kontribusi yang diberikan Bait al-Hikmah bagi kemajuan kebudayaan, khususnya di bidang ilmu pengetahuan.

\section{MOTIVASI BERDIRINYA BAIT AL-HIKMAH}

Sebagaimana disinggung sebelum ini, bahwa dorongan keilmuan bagi kaum muslim sejak awal merupakan dinamika internal yang muncul dari nilai religius yang diyakininya, bahwa menuntut ilmu itu merupakan perintah dan kewajiban dalam agama. Kemudian pada tahap kehidupan keberagamaan lebih lanjut, muncul pula kebutuhan-kebutuhan yang mulai mengarah pada perlunya petunjuk-petunjuk "teknis" dalam pelaksanaan

${ }^{6}$ Hasan Ibrahim Hasan, Sejarah dan Kebudayaan Islam: 632-1968, terj. Djahdan Humam (cet. ke-1; Yogyakarta: Kota Kembang, 1989), h. 132.

${ }^{7}$ Dalam catatan historis Hitti dijelaskan bahwa masa itu benih sudah ditabur dan pohon pengetahuan yang bertumbuh dengan megahnya dlam zaman ahalla yang berikut di Baghdad, tentu sekali sudah berakar dalam zaman yang telah lampau, yaitu zaman kebudayaan Yunanai, Syiria dan Parsi. Zaman Dinasti Umaiyah pada umumnya adalah masa inkubasi (masa tunas). Philip K. Hitti, Dunia Arab Sejarah Singkat terj. Ushuluddin Hutagalung dan ODP. Sihombing (cet. ke-7; Bandung : Sumur Bandung, t.th.), h. 101. 
ritual keagamaan. Seperti menetapkan arah kiblat dalam salat menyebabkan munculnya perhatian dan kebutuhan terhadap penyelidikan di bidang astronomi. ${ }^{8}$

Berbagai upaya untuk memahami dan menelusuri ajaran dan sumber ajaran Islam, dengan sendirinya memunculkan disiplin-disiplin ilmu tertentu (sebagai buah dari rihlah ilmuwan ). Misalnya, untuk dapat menafsirkan dan memahami maksud suatu ayat, diperlukan pengetahuani tentang sebab-sebab turunnya ayat (dari situ muncul ilmu Asbāb al-Nuzūi); untuk dapat memahami suatu hadis diperlukan pengetahuan tentang riwayat hidup perawinya (dari situ muncul ilmu rijāl al-hadīś) dan seterusnya. ${ }^{9}$

Karena dorongan internal tersebut maka semangat pengembaraan intelektual kaum muslim makin hari makin meninggi dan meluas, seiring dengan perluasan wilayah yang dikuasainya, sehingga konsekuensinya terjadilah persentuhan dengan budaya luar, yaitu budaya Yunani Helenisme dan Helenistik serta Parsi. ${ }^{10}$

Persentuhan dengan budaya luar telah dimulai sejak masa Dinasti Umayyah dan melangkah seiring dengan perluasan kekuasaan kaum muslim dan mencapai puncaknya pada masa kekhalifahan Abbasiyah yang brillian, khususnya, khuususnya pada masa al-Rasyīd dan al-Ma'mūn. ${ }^{11}$

Bila dipertanyakan lebih lanjut mengenai faktor-faktor yang menyebabkan terjadinya transimisi Hellensistik yang demikian gencar ke pangkuan kaum muslim, tentu berbagai hal dapat

${ }^{8}$ Ibid., h. 117.

${ }^{9}$ Shiddiqi, Tamaddun...., h. 1.

${ }^{10}$ Helenistic ialah hal-hal yang berkenaan dengan Yunani; sedangkan Hellenisme: berkenaan dengan kebudayaan Yunani Kuno; Hellenic : berkenaan dengan Hellenistic. Lihat, Pieter Salim, The Contemporary English-Indonesia Dictionary (Third Edition; Jakarta: Modern English Press, 1987), h. 862

${ }^{11}$ H.A.R. Gibb, Mohammadanism: A Historical Survey (Second Edition; London: Oxford University Press, 1953), h. 4-5. 
dikemukakan. Namun demikian, dari sekian banyak penyebab, ada empat penyebab yang dapat dipandang sebagai faktor historis yang penting, yaitu :

- Terusirnya sekte-sekte Nestorian dan Monophysit oleh Kristen Ortodox (di pihak penguasa Byzantium) karena perbedaan dokrinal. Mereka terpaksa mencari tempat/kebudayaan yang lebih bersahabat untuk dapat mempertahankan kebudayaannya. Akhirnya mereka sampai dan tersebar ke kawasan-kawasan kekaisaran Persia dan dunia Arabia. Mereka membawa warisan ilmu pengetahuan Gerico-Hellenistik terutama ilmu kedokteran, matematika, astronomi, filsafat dan mengembangkannya pada kawasan baru yang mereka diami. Ketika kaum muslim menaklukan kekaisaran Romawi dan Persia, setidak-tidaknya minoritas ini menyambut kaum muslim (sebagai penakluk yang toleran) dan menjalin hubungan yang bersahabat. Melalui kelompokkelompok inilah jalur transmisi ilmu pengetahuan terbentuk;

- Penaklukan oleh Alexander Agung dan penggantinya, yang dengannya terjadi penyebaran pengetahuan dan Hellenistik mencapai Mesir, India, dan Persia, kemudian dikembangkan dan diperkaya dengan pemikiran-pemikiran asli;

- Faktor yang dapat dianggap terpenting adalah Akademi JundiShapur kekaisaran Persia yang memadukan tradisi ilmiah berbagai budaya: India, Grecian, Syria, Hellenistik, Hebrew, dan Persia. Jundi Shapur menggalakkan penerjemahanpenerjamahan ke dalam bahasa-bahasa Pahlavi dan Syria, sampai bangkitnya Baghdad, Sisilia, dan Cordova. 
- Kegiatan ilmiah Yahudi, juga signifikan dengan usaha penerjamahan karya-karya Yunani ke dalam bahasa Hebrew dan Arab sampai dengan masa awal Islam. ${ }^{12}$

Apa yang dapat dipahami dari kutipan tersebut adalah bahwa pada saat Islam mulai merentangkan pengaruh ke dunia sekitarnya, tampaknya suasana lapangan, khususnya dalam bidang budaya (filsafat dan ilmu pengetahuan serta seni), sudah memang kondusif. Hanya pada masa-masa awal terjadinya persentuhan, pihak kaum muslim sendiri nampaknya belum sampai pada tingkat "kesiapan" yang prima. Sebagaimana diungkap Hawting dalam The First Dynasty of Islam sesuai dengan pandangan Stanton bahwa:

Mesti bersentuhan dengan filsafat dan teologi Hellenistik, Bani Umaiyah tidak begitu tertarik untuk memajukan kajian filsafat dan teologi. Mereka lebih tertarik pada pengembangan kekuasaan dan kerajaannya. ${ }^{13}$

Padahal, dalam kontak dan pergaulan dengan orang-orang terpelajar, baik yang belum maupun yang baru menganut Islam, cendekiawan muslim saat itu tidak selalu siap untuk menjelaskan agamanya sesuai dengan kerangka rasionalisme Yunani. Sementara itu dalam filsafat Yunani terdapat alat dan contoh konseptualisasi suatu sistem kepercayaan dan alat untuk menyajikan argumen-argumennya dengan cara rasional kepada orang-orang yang baru dan mau masuk Islam. Oleh karena itu, untuk menghadapi tantangan ini, mereka memutuskan untuk mempelajari metode-metode dialektik logika dan retorika dari Yunani itu. ${ }^{14}$

${ }^{12}$ Mehdi Nakosteen, Kontribusi Islam atas Dunia Intelektual Barat; Deskripsi Analisis Abad Keemasan Islam, terj. Joko S. Kahar dan Supriyanto Abdullah (cet. ke-1: Surabaya: Risalah Gusti, 1996), h. 18-20.

${ }^{13}$ Charles Michael Stanton, Pendidikan Tinggi dalam Islam, Sejarah dan Peranannya dalam Kemajuan Ilmu Pengetahuan, terj. Afandi dan Hasan Asy'aril (cet. ke-1; Jakarta: Logos, 1984), h. 80.

${ }^{14}$ Ibid., h. 80-81 
Apa yang disinyalir oleh Hawting tentang ketertarikan Bani Umaiyah pada pengembangan kekuasaan dan kerajaan lebih daripada terhadap ilmu pengetahuan, serta sinyalemen Stanton tentang kebutuhan kaum muslim akan ilmu pengetahuan (Hellenistik) untuk menyikapi kontak yang sudah ramai dengan orang luar/orang baru, merupakan hal yang wajar sebab, selain sebagai seorang negarawan, Mu'awiyah yang memandang kestabilan merupakan prasyarat mutlak untuk dapat menjalankan pemerintahan dengan baik, masa-masa tersebut juga merupakan masa ekspansi yang dapat mengundang terjadinya kontak yang ramai dengan dunia luar. Selain itu, walaupun tidak begitu tertarik terhadap pengembangan ilmu pengetahuan, ia tidak melarangan upaya pengembangan ilmu pengetahuan. Dengan demikian, kontak intelektual itupun tetap dapat berlangsung, walapun dalam dinamika yang agak lamban. Sampai tiba masa kekhalifahan Abbasiyah yang diantara para khalifahnya merupakan ilmuwan-ilmuwan dan pecinta-pecinta ilmu pengetahuan. Hasilnya, pada masa Harun al-Rasyīd sudah mulai didirikan lembaga-lembaga penterjemah. Syalabi yang merujuk ke Al-Fihris (karya yang ditulis Ibnu Nadìm) mengungkapkan bahwa Abū Sahl al-Faḍl Ibn Naubacht dulu bekerja di bawah Hārūn al-Rasyīd pada Khizānah Al-Hikmah . ${ }^{15}$

Kegiatan penterjemahan mencapai puncaknya pada masa kekhalifahan al-Ma'mūn. Hal ini didorong oleh kepribadian Khalifah al-Ma'mūn yang memiliki kecerdasan yang luas, sangat

\footnotetext{
${ }^{15}$ Ahmad Syalabi, History of Muslim Education, terj. penulisanya ke bahasa Arab oleh penulisnya dengan judul Tarikh al-Tarbiyhah al-Islamiyah dan ke bahasa Indonesia Sejarah Pendidikan Islam, terj. Muchtar Jahja dan Sanusi Latif (Jakarta: Bulan Bindtang, t.th.) h. 170. Keterangan lebih lanjut tentang telah adanya Khizānah al-Hikmah sejak masa Hārūn al-Rasyīd, yang berfungsi selain sebagai perpustakaan yang dipimpin oleh Ibnu Naubacht, juga bergungsi sebagai lembaga penerjemah literatur-literatur Greek, dapat dilihat pada The Encyclopedia of Islam, New Edition, H.R. Gib, et al. (Eds.) Volume I (Leiden: t.p., 1960), h. 1141. Bandingkan Tim Penulis IAIN Syarif Hidayatullah, Ensiklopedi Islam (Jakarta: Djambatan, t.th.) h. 159.
} 
mencintai ilmu pengetahuan, kebudayaan dan sastra sehingga ia menumpahkan perhatiannya pada kegiatan penterjemahan dan kegiatan keilmuan lainnya. ${ }^{16}$

Hārūn al-Rasyīd dan al-Ma'mūn yang dikenal sebagai pendukung Mu'tazilah yang rasionalis menggalakkan perkembangan ilmu pengetahuan di berbagai bidang, seperti hukum, teologi, dan bahasa Arab yang merupakan hasil pemikiran sendiri dan filsafat, kedokteran, matematika, kimia, astronomi, ilmu bumi, dan sejarah, yang dimulai dari usaha penterjemahan. Untuk menggalakan usaha penterjemahan tersebut maka didirikanlah sebuah Perguruan Tinggi Bahasa (Yunani, Persia, India) dari sebuah Dewan Penterjemahan yang diberi nama Bait al-Hikmah. ${ }^{17}$

\section{EKSISTENSI BAIT AL-HIKMAH}

Dari analisis tentang motivasi dan latar belakang yang mendorong terbentuknya Bait al-Hikmah seperti tersebut di atas, dapat dikemukakan bahwa berdirinya Bait al-Hikmah merupakan proses yang wajar dari perjalanan sejarah perkembangan kaum muslim sendiri.

Bagaikan gayung bersambut, kondisi tersebut berlangsung terus-menerus di kalangan khalifah Abbasiyah yang mencintai ilmu, khususnya al-Mansyūr, al-Rasyīd dan al-Ma'mūn. Sejak masa al-Mansyur kegiatan, keilmuan yang antara lain penerjemahan mulai meningkat. Pada masa al-Rasyīd kegiatan penerjemahan sudah mulai dikembangkan dengan didirikannya Khizānah al-Hikmah yang dikelola Ibnu Naubacht.

Semangat dan kiprah keilmuan kaum muslim mendapat tempat yang sangat kondusif pada masa al-Ma'mūn, khalifah ke-7

\footnotetext{
${ }^{16}$ Syalabi, ibid. Dapat pula dibaca karya Montgomeri Watt, Kejayaan Islam: Kajian Kritis dari Tokoh Orientalis, terj. Hartono Hadikusumo (Yogyakarta: Tiara Wacana, 1990), h. 68.

${ }^{17}$ Shiddiqi, Tamaddun ..., h. 13.
} 
Dinasti Abbasiyah. Kecintaan al-Ma'mūn kepada ilmu pengetahuan dapat dilihat dari perhatian dan pendanaan bagi kegiatan penterjemahan, dan dengan mengembangkan lembaga yang pernah didirikan ayahnya al-Rasyīd, menjadi Bait alHikmah.

Bait al Hikmah kata Hitti merujuk Ibnu Nadīm -didirikan al-Ma'mūn pada 830 M./215 H., sebagai wujud ketertarikannya pada rasionalitas dan pengakauannya atas pertautan antara rasionalitas dengan ajaran agama. Bait al-Hikmah yang didirikan di Baghdad merupakan perpaduan bentuk kelembagaan/Institusi Akademi, perpustakaan dan Biro Penerjemahan. ${ }^{18}$

Yahyā Ibn Khalīd al-Barmakī, seorang Persia dan berpendidikan Persia-sebagai pejabat kenegaraan bidang pengawasan dan kebangkitan ilmu pengetahuan saat itumenunjuk beberapa orang yang mengusai bahasa Persia selain bahasa Arab antara lain : Abū Sahl al-Faḍl Ibnu Naubacht dan Allan al-Syu'bī (yang sudah bekerja pada Khizānah al-Hikmah masa al-Rasyīd) untuk menterjemahkan aneka buku berbahasa Persia dan India yang dipesannya, ke dalam bahasa Arab. ${ }^{19}$

Bait al-Hikmah yang didirikan al-Ma'mūn di istananya, ${ }^{20}$ merupakan penggabungan fungsi perpustakaan, pusat pendidikan tinggi, sanggar sastra, lingkaran studi, observatorium sekaligus kesemuanya di bawah pengawasan khalifah. Berkat hubungan Khalifah al-Ma'mūn yang luas maka didatangkanlah bahan-bahan terjemahan berupa buku, manuskrip-manuskrip filsafat dan ilmu pengetahuan lainnya dari karya bangsa Yunani, baik dari

${ }^{18}$ Philip K. Hitti, History of The Arab (Ninth Edition, Macmillan New York: St. Martin's Press, 1968) h. 310. Bandingkan dengan, Bayard Dodge, Muslim Education in Medieval Times (Washington D.C : The Middle Eas Institute, 1962), h. 16.

${ }^{19}$ Syalabi, Sejarah Pendidikan Islam ..., h. 171.

${ }^{20}$ Stanton, Pendidikan Tinggi..., h. 83. 
Byzantium maupun Jundi Shapur. ${ }^{21}$ Untuk mengurusi perbendaharaan yang sedemikian banyak maka diangkatlah Sahl ibnu Harun sebagai Sekretaris Bait al-Hikmah. ${ }^{22}$ Sedangkan sebagai Kepala Bait al-Hikmah ditunjuk Yuhanna bin Musāwaih pada tahun $830 \mathrm{M} .(215 \mathrm{H})$ saat pendiriannya. Berkat pengalamannya mengelola lembaga pendidikan di Jundi Shapur, Yuhanna berhasil menjadikan Bait al-Hikmah sebagai lembaga yang multi fungsi. ${ }^{23}$

Dalam statusnya sebagai lembaga penterjemah, Bait alHikmah memiliki banyak penterjemah yang handal, walaupun pada masa-masa awalnya kebanyakan dari mereka adalah non muslim. Hal ini dapat dipandang wajar, sebab penterjemahan memerlukan keterampilan penguasaan selain bahasa Arab, juga bahasa asli bahan yang diterjemahkan (Yunani, Persia dan Hebrew).

Di antara penterjemah yang paling handal adalah Hunain Ibn Ishāā, yang didatangkan al-Ma'mūn pada saat masih muda remaja dan disuruh menyalin kitab-kitab yang ditulis oleh orangorang pintar Yunani ke dalam bahasa Arab, serta memperbaiki salinan-salinan yang dikerjakan oleh orang lain. ${ }^{24}$ Pada masamasa berikutnya, Hunain ibn Ishāa dipercayai memimpin Bait alHikmah dilanjutkan anaknya, Isḥāq ibn Hunain. ${ }^{25}$

Kehandalan Hunain diakui banyak penulis sejarah. Hitti menulis bahwa Hunain Ibn Ishāq (Joannitus, 809-876) merupakan Syekh di antara para penterjemah-demikian orang Arab menyebutnya-salah seorang sarjana paling besar dan terhormat pada zaman itu, ia adalah seorang Kristen Nestorian. Kehandalannya sebagai penterjemah dinyatakan dalam sebuah

\footnotetext{
${ }^{21}$ Ibid., h. 164

${ }^{22}$ Syalabi, Sejarah Pendidikan Islam..., h. 171.

${ }^{23}$ Tim Penulis IAIN Syahid, Ensiklopedi Islam..., h. 160.

${ }^{24}$ Syalabi, Sejarah Pendidikan Islam...., h. 172.

${ }^{25}$ Stanton, Pendidikan Tinggi ..., h. 83.
} 
laporan bahwa dirinya dan lainnya dibayar 500 dinar per bulan, dan al-Ma'mūn membayarnya dengan emas seberat buku yang diterjemahkannya. ${ }^{26}$

Di antara para penterjemah ternama yang aktif di Bait alHikmah adalah Ibnu al-Bitriq, Yuhanna Ibnu Maswaih, Hunain ibn Isḥāq sendiri dan anaknya Isḥāq Ibn Hunain, Muḥammad Ibn Mūsā al-Khawāriznī, Said Ibn Hārūn, Ṡābit Ibn Qurrah dan Umar Ibn al-Farrakhān. ${ }^{27}$ Orang yang juga setara dengan Hunain adalah Gesta Ibn Lukā al-Ba'labaki atau Ibnu Lukā, selain menterjemah juga dipercaya merevisi terjemahan yang lebih tua. ${ }^{28}$

Di antara buku yang diterjemahkan Hunain adalah karyakarya Galenus, Hypocrates dan Dioscorides. Karya Plato, Republic, karya-karya Aristoteles: Categories, Physics, dan Magna Moralita. Yang jelas seluruhnya karya Galenus tentang anatomi tujuh, dalam bahasa aslinya, bahasa Yunani sudah hilang, untung ada yang ditemukan dalam bahasa Arab. ${ }^{29}$

Dalam keterangan yang lebih rinci, Nakosteen, menyebutkan para penterjemah beserta jumlah terjemahannya, yang bahkan masih ada tersimpan sampai sekarang di berbagai perpustakaan yang tersebar di berbagai belahan bumi ini - angka dalam kurung menunjukan jumlah buku terjemahan, yakni:

Hunain ibn Ishāq (11), Gasta ibn Lukā (7), Hubaisy ibn Husain al-Āsānī (5), İsā ibn Yahyā (2), Hajjāj ibn Yūsuf Ibn Metran (2), Ṡābit ibn Qurrā alHaran̄̄ (15) A $\bar{b} \bar{u}$ Uśmān Sā'id ibn Ya'qūb al-Dimasyqī (19), Istipan ibn Basīl (1), Astaś (2), 'Abd al-Masīh ibn 'Abd Allāh al-Hams al-Na'īmī (Ibn

${ }^{26}$ Dalam teks aslinya a.l. ditulis: The sheikh of the traslators, as the Arabs express it, was Hunain ibn Ishaq (Joannitus, 809-73), one of the greatest scholar and noblest character of the age. Hunain was an Ibad, i.e a Nestorian Christian .... Hunain's ability as a translator may be attested by the report that when in the service of the sons of Ibnu Shahir he and other translators recieved about 500 dinars per month and that al-Ma'mun paid him in gold the weight of the books he translated. Hitti, History..., h. 312-313.

${ }^{27}$ Syalabi, Sejarah Pendidikan Islam..., h. 172.

${ }^{28}$ Nakosteen, Kontribusi Islam..., h. 38

${ }^{29}$ Hitti, History..., h. 313. 
Na'īmī) (2), Abū Basyar Mala ibn Yūnus al-Ghanā'î (3), Abū Zakariyā Yahyyā ibn Ada (1), Ibn Zara (1), Madīf al-Ghas al-Rūmī (1), Ibn WahSyiyijat al-Kaldānī (2), Hiilāl ibn Abī Hilāl al-Himdi (1), Basil al-Mitran (1), Ṭadars al-Sanghal (al-Taśarī) (1), Ibrāhim ibn Abd Allāh al-Nasrānī alKātib (2), Ishāq ibn Abī al-Ḥasan ibn Ibrāhim (1), Sirjis (Sirgins) ibn Hulya (Elia) al-Rumi (1). ${ }^{30}$

Nakosteen tidak menjelaskan berapa banyak karya-karya keilmuan yang berasal dari peradaban non Islam yang diterjemahkan ke dalam bahasa Arab. Dalam kutipan tersebut hanya disebutkan terjemahan-terjemahan yang masih ada sampai sekarang. Penulis tidak menemukan jumlah yang pasti tentang seluruh perbendaharaan keilmuan yang ditransfer ke dalam bahasa Arab selama keberadaan Bait al-Hikmah. Mungkin lebih banyak dari yang disebutkan itu, namun bisa jadi tidak ditemukan lagi oleh para peneliti atau penulis sejarah.

Menurut Nakosteen, prosedur penterjemahan memiliki beberapa tahapan atau tipe dasar yaitu (1) materi secara langsung diterjemahkan dari bahasa Yunani ke dalam bahasa Arab; (2) materi diterjemahkan ke dalam bahasa Syria, kemudian diterjemahkan ke dalam bahasa Arab; dan (3) materi diterjemahkan dari Hindia/India ke bahasa Pahlavi kemudian ke bahasa Syiria lalu ke bahasa Arab. Ada juga karya yang pada dasarnya merupakan ulasan/ikhtisar dari karya-karya GrecoPersian yang kemudian dikembangkan pada masa pra Islam. Kemudian setelah melalui tahapan yang agak panjang, sampai menjelang akhir abad ke-9 dan pada abad ke-10 kaum muslim mulai lebih secara mandiri berkreativitas dalam pengembangan ilmu pengetahuan. ${ }^{31}$

Pada awalnya sebagian penterjemahan dilakukan kata per kata sehingga agak sulit dipahami, bahkan kata yang sulit dicarikan padanannya, bahasa aslinya di alihkan apa adanya. ${ }^{32}$

\footnotetext{
${ }^{30}$ Nakosteen, Kontribusi Islam..., h. 40-41.

${ }^{31}$ Ibid., h. 19.

${ }^{32}$ Stanton, Pendidikan Tinggi ... ,h. 82.
} 
Para penterjemah yang datang kemudian menyalin dan menyempurnakannya kembali. Dalam usaha penterjemahan iniNourouzzaman Shiddiqi-merujuk kepada Hitti dalam History of the Arab-mengatakan bahwa para penterjemah tidak sekedar menterjemahkan, tetapi telah pula memasukan buah pikiran mereka. Dengan cara yang demikian maka buku-buku Plato dan Aristoteles, Galen dan Ptolemius yang sulit dipahami dalam bahasa aslinya, menjadi jelas setelah diterjemahkan. Selain itu, mereka juga menyajikan hasil-hasil temuan mereka sendiri, di bidang hukum, teologi dan ilmu bahasa (Arab) sepenuhnya hasil temuan dan kajian asli mereka sendiri. Demikian pula halnya dengan karya-karya terjemahan yang tidak kalah penting dari penemuan baru. Alasannya, jika hasil-hasil kajian Aristoteles, Galen dan Ptolemius tidak digali kembali dari "kuburnya", kemudian dibersihkan dan disempurnakan maka prestasi yang telah pernah dicapai umat manusia pasti telah musnah. ${ }^{33}$

Dari analisis tersebut terlihat betapa penting dan strategisnya posisi Bait al-Hikmah sebagai lembaga penerjemahan demi kesinambungan dan pelestarian prestasi budaya manusia. Dari situ pula dapat dipahami tanpa mengurangi posisinya yang lain bahwa Bait al-Hikmah sebagai lembaga penerjemahan menempati posisi dominan.

Dalam kedudukannya sebagai perpustakaan, Bait al-Hikmah merupakan perpustakaan yang pertama kali didirikan di dunia Islam yang mempunyai kedudukan yang tinggi. Buku-buku yang didatangkan dari Yunani, disusun di Bait al-Hikmah menurut bidangnya masing-masing. Penyalin-penyalin ke dalam bahasa Arab dipilih di antara orang yang mahir dalam masing-masing bidang, selain menguasai bahasa Yunani dan Arab. ${ }^{34}$

Namun demikian, sebagai perpustakaan, Bait al-Hikmah pada dasarnya merupakan kelanjutan dari Khizānah al-Hikmah

${ }^{33}$ Shiddiqi, Tamaddun..., hh. 13, 20.

${ }^{34}$ Syalabi, Sejarah Pendidikan Islam...,h. 172. 
yang didirikan al-Rasyīd, ayah al-Ma'mūn, tetapi sebagai perpustakaan yang profesional dibuka untuk umum, para penulis sejarah sepakat, bahwa itu dimulai pada masa al-Ma'mūn, dan sebagai perpustakaan, fungsinya sangat terkait dengan Bait alHikmah sebagai lembaga penerjemahan.

Menurut Stanton, "Perpustakaan dan pusat pendidikan tinggi yang paling terkenal di Baghdad selama masa kepemimpinan al-Ma'mūn adalah Bait al-Hikmah. Perpustakaanperpustakaan yang dibangun untuk umum terdiri atas ruanganruangan yang dilengkapi dengan karpet-karpet dan meja-meja yang mewah, tinta dan kertas yang tersedia bagi para ilmuwan dan mahasiswa. Di beberapa perpustakaan besar, khususnya di Baghdad dan Kairo, sebanyak 40-50 ruangan dibangun untuk menyimpan buku-buku dan untuk ruang belajar bagi para ilmuwan dan mahasiswa. Manuskrip-manuskrip ditata di rak-rak sedemikian rupa sehingga para pengunjung dapat dengan mudah menemukannya. Perpustakaan-perpustakaan itu menyimpan buku-buku dari semua bidang, dari buku-buku yang berasal dari bangsa Timur dalam bahasa Sangsekerta sampai karya-karya terjemahan bahasa Arab atas buku-buku sains dan filsafat bangsa Yunani. Jumlah seri (volume) buku yang ada di perpustakaan umum sulit diperkirakan, tetapi banyak perpustakaan dilaporkan memiliki antara 100.000 dan 1.000 .000 volume. $^{35}$

Syalabi seperti halnya Hitti memandang Bait al-Hikmah sebagai institusi multi fungsi. Selain sebagai perpustakaan yang pertama bahkan pembahasannya, Bait al-Hikmah disebut sebagai "Perpustakaan Umum". Syalabi juga memandang Bait al-Hikmah sebagai institusi pendidikan, sebagaimana ia kemukakan bahwa:

Bait al-Hikmah adalah universitas yang pertama sekali tempat berkumpul-nya ulama-ulama dan penyelidik-penyelidik ilmiah, pelajarpelajar dan mahasiswa-mahasiswa. Dengan demikian, Bait al-Hikmah adalah suatu "Pusat Ilmu Pengetahuan" yang pertama kali, yang telah menyumbangkan ilmu pengetahuan yang teramat banyak kepada

${ }^{35}$ Stanton, Pendidikan Tinggi..., h. 167, 169. 
penuntut-pentuntutnya, terutama sekali dalam bidang kedokteran, filsafat hikmah, dll. ${ }^{36}$

Dalam fungsi/posisinya sebagai institusi pendidikan ini, tidak ditemukan keterangan rinci tentang bagaimana kondisi kurikulum, guru/dosen dan mahasiswa, baik dari segi jumlah maupun komposisi usia, dan sebagainya. Hanya ditemukan kesan bahwa kebesaran citra Bait al-Hikmah selain sebagai lembaga penterjemahan adalah sebagai lembaga pendidikan. Keberadaannya sebagai lembaga pendidikan tinggi hanya dapat dipahami melalui keterangan atau komentar yang sifatnya umum, seperti yang dikemukakan Stanton bahwa:

Di bawah pimpinan Hunain dan anaknya, pusat penterjemahan itu (Bait al-Hikmah) mengangkat sekelompok ilmuan yang brillian dan diberikan hak untuk mengkaji dan mengajarkan manuskrip-manuskrip yang baru dan langka, begitu juga laboratorium perbintangan (observatorium) dengan perlengkapan yang baik. Di Bait al-Hikmah itu, al-Kindī mendirikan sekolah berbahasa Arab (yang mengajarkan) filsafat peripatetik yang kemudian dikembangkan oleh al-Farābī, Ibn Sinā dan Ibn Rusyd. Di tempat ini juga al-Khawāriznī tidak hanya memberikan sumbangan bagi filsafat, teologi, dan matematika, tetapi juga melakukan penelitian di laboratorium perbintangan. ${ }^{37}$

Nourouzzaman Shiddiqi juga menjelaskan bahwa untuk kepentingan Bait al-Hikmah, Khalifah al-Ma'mūn membangun sebuah obserbatori astronomi, dan Sa'īd 'Ālī dan Yahyā ibn Abī Manșūr ditunjuk sebagai pemimpinnya dan sebagai peneliti ahli diangkat pula oleh khalifah seorang ahli matematika dan astronomi yang brillian, al-Khawāriznī. Para ahli dari lembaga ini tidak hanya membuat observasi sistematik terhadap gerakangerakan benda-benda di langit tetapi juga membuktikan secara tepat unsur-unsur fundamental yang terdapat dalam Almagest (karya Ptolemius) tentang garis gerak yang tidak beraturan dari garis edar matahari, sepanjang tahun syamsiah dan sebagainya. ${ }^{38}$

\footnotetext{
${ }^{36}$ Syalabi, Sejarah Pendidikan Islam..., h. 172

${ }^{37}$ Stanton, Pendidikan Tinggi...., h. 169

${ }^{38}$ Shiddiqi, Tamaddun..., h. 29.
} 
Sepeninggal al-Ma'mūn, peran penting Bait al-Hikmah terus merosot setelah masa tekanan (pemberangusan) gerakan rasional. Posisi tradisional yang diambil alih oleh khalifahkhalifah sesudah itu, memperlemah dukungan intelektual Bait alHikmah. Namun demikian, Bait al-Hikmah terus berjalan (tetap hidup) sebagai sebuah sekolah istana sampai masa penghancuran oleh pasukan Mongol atas kota Baghdad pada tahun 1258 M. di mana Bait al-Hikmah ikut dibakar. ${ }^{39}$

Dari paparan dan analisis tentang posisi/fungsi Bait alHikmah sebagai institusi penterjemahan, institusi perpustakaan, institusi pendidikan serta observatorium, nampaknya memperkuat citra Bait al-Hikmah sebagai lembaga yang menyelenggarakan fungsi pendidikan tingkat tinggi dalam pengertian yang sesungguhnya. Sehingga tampak cocok untuk disebut sebagai pusat ilmu pengetahuan pada masanya yang berpengaruh melampaui masanya. Tetapi bila dipandang dengan kacamata perangkat Universitas modern, tentu tidak akan sepenuhnya pas.

\section{KONTRIBUSI BAIT AL-HIKMAH}

Dengan mencermati paparan dan analisis tentang berbagai posisi/fungsi yang dapat dan telah dimainkan Bait al-Hikmah , baik sebagai lembaga penterjemahan, lembaga pendidikan, perpustakaan, lembaga riset/observatorium, dapat dipahami betapa besar kontribusi yang telah diberikan kepada masyarakat pada masa itu maupun masa sesudahnya.

Dalam History of the Arab, Hitti memaparkan bahwa:

Sebelum masa penterjemahan berakhir (masih efektifnya Bait al Hikmah), semua karya-karya Aristoteles sudah dibaca oleh orang-orang berbahasa Arab. Ini terjadi tatkala Eropa hampir belum mempunyai pengetahuan apa-apa tentang alam pikiran dan ilmu pengetahuan Yunani. Tatkala Harun al-Rasyīd dan al- Ma'mun sudah giat menyelami

${ }^{39}$ Syalabi, Sejarah Pendidikan Islam..., h. 173. Bandingkan dengan Stanton, Pendidikan Tinggi...,h. 169.. 
filsafat Yunani dan Parsi, orang-orang di zaman mereka di dunia Barat, yakni Karl Agung dan kaum ningratnya, masih mencakar-cakar untuk menulis namannya. ${ }^{40}$

Dalam mempersepsikan daya dorong dari pengaruh aktivitas dan keberadaan Bait al-Hikmah, Syalabi menganalisis lebih lanjut bahwa Bait al-Hikmah ini membawa perkembangan yang pesat dalam bidang ilmu pengetahuan, kebudayaan dan sastra di kalangan kaum muslim. Ilmu pengetahuan asing dimasukan, lantas dikuasai dan dimiliki oleh kaum muslim. Dengan demikian perbendaharaan ilmiah ini jadi terpelihara, dan dapat dipusakakan kepada generasi-generasi yang datang kemudian, dikala hampir-hampir saja lenyap dan musnah. ${ }^{41}$

Dengan tidak bermaksud mengabaikan yang lainnya, untuk sekedar menyebut contoh refresentasi dari output yang dapat dipandang sebagai sumbangan Bait al-Hikmah bagi kebudayaan dan peradaban pada masanya maupun sesudahnya, di sini dicoba kemukakan beberapa pandangan.

Bahasa Arab, yang dalam zaman pra Islam hanya merupakan bahasa puisi, dan sesudah Nabi Muhammad saw., terutama sebagai bahasa wahyu dan agama, maka di sekitar abad ke-10 M. dengan cara aneh dan belum pernah terjadi, menjelma menjadi suatu alat komunikasi ilmiah dan filosofis, juga sebagai bahasa politis. ${ }^{42}$

Usaha penyelarasan alam pikiran Yunani dengan buah pikiran Islam, yang ditangani al-Kindi (w. 260/873) diteruskan alFarabi (w. 340/950) dan Ibnu Sina (w. 428 H./1037M.), bahkan dipandang sebagai "penjinak" dan penyelamat alam

\footnotetext{
${ }^{40}$ Hitti, Dunia Arab..., h. 315.

${ }^{41}$ Syalabi, Sejarah Pendidikan Islam...., h. 170.

${ }^{42}$ Hitti, Dunia Arab..., h. 121.
} 
pikiran/filsafat Yunani, yang sangat berpengaruh bagi kelangsungannya sampai seterusnya. ${ }^{43}$

Kemudian nama-nama seperti al-Khawāriznī ahli astronomi dan matematika, Jābir ibn Hayyān ahli ilmu kimia, dan sejumlah nama besar dengan keahlian dan karyanya masing-masing. ${ }^{44}$

Hal senada juga diungkap Nourouzzaman Shiddiqi bahwa era Bait al-Hikmah melahirkan tokoh-tokoh ilmu pengetahuan dan para hukama seperti Musa al-Khawāriznī (w. 236/850), alKindi, al-Farabi yang mendapat julukan al-Mu'allim al-śānī (guru kedua di mana guru pertama ialah Aristoteles), dan Ibnu Sina. Merujuk ke Stanton dalam karya Introduction to the History of Science, ia menyatakan "Tugas pokok kemanuisaan telah dikerjakan oleh orang-orang Muslim ..."

Karya-karya terjemahan yang telah disempurnakan dengan pemikiran baru para penterjemah ahli, yang kemudian dibukukan kemudian disebarkan ke Eropa melalu Syria, Spanyol (Andalusia) dan Sicilia. Itulah yang menjadi basis yang dominan dalam perkembangan ilmu pengetahuan di Barat yang terjadi sejak awal era Renaisans. Bahkan karya-karya itulah yang mendorong terjadinya era Renaisans di Barat. ${ }^{46}$

\section{PENUTUP}

Latar belakang didrikannya Bait al-Hikmah di antaranya karena dorongan faktor internal dari keyakinan atas nilai ajaran agama yang selalu mendorong pemeluknya untuk belajar dan menuntut ilmu. Kemudian karena dorongan kebutuhan kaum

\footnotetext{
${ }^{43}$ Hitti, ibid., h. 143-144 dan Nurcholish Madjid, (Ed.), Khazanah Intelektual Islam (Jakarta : Bulan Bintang, 1984), h. 23-32.

${ }^{44} \mathrm{Hitti}$, Dunia Arab..., h. 145-151. Tentang seni dan sastra, pada dasarnya Arab tidak mendapat pengaruh langsung dari Yunani karena memang tidak di "sentuh", tapi justru dari Parsi tentang ini lihat bukunya Hitti dan sebagainya, h. 118.

${ }^{45}$ Shiddiqi, Jeram-Jeram..., h. 33-34.

${ }^{46}$ Shiddiqi, Tamaddun..., h. 20.
} 
muslim dalam melaksanakan syariat agamanya, serta untuk memudahkan dalam mendakwahkan agamanya, baik terhadap yang baru memeluk Islam, maupun yang sudah lama tetapi perlu/ingin mengetahu Islam secara lebih dalam, terutama dari kalangan intelektual. Selain itu, kondisi pada masa itu sangat kondusif untuk mentransfer khazanah Yunani dan Parsi ke dalam pelukan kaum muslim. Selain itu, para penguasa di sekitar masa menjelang berdirinya Bait al-Hikmah adalah orang-orang yang mencintai ilmu pengetahuan.

Eksistensi Bait al-Hikmah adalah--selain fungsinya yang pertama sejak didirikan Khalifah al-Ma'mūn (830 M. (215 H.)-sebagai lembaga penterjemah filsafat dan ilmu pengetahuan Yunani dan Parsi ke dalam bahasa Arab, juga sebagai perpustakaan dan lembaga pendidikan tinggi serta semacam lembaga riset yang memiliki observatorium untuk penelitian perbintangan. Keberadaannya yang paling terkenal adalah sebagai lembaga penterjamahan selain sebagai lembaga pendidikan tinggi. Bait al- Hikmah mencapai masa jayanya pada masa al-Ma'mūn, namun tetap berjalan dan hidup sampai Hulagu menghancurkan Baghdad pada tahun 1258 M. (656 H.) di mana Bait al-Hikmah ikut dibakar.

Bait al-Hikmah memiliki daya dorong, baik langsung maupun tidak langsung, yang cukup besar dan luas terhadap kemajuan kebudayaan dan peradaban pada masa Abbasiyah umumnya (khususnya masa-masa awal), bahkan sejak era Bait alHikmah telah bermunculan filusuf dan ilmuwan Muslim yang hasil-hasil karyanya dapat dipandang monumental dan berpengaruh dominan bagi kemajuan ilmu pengetahuan pada umumnya, bahkan dalam mendorong menculnya Renaisans di dunia Barat.

\section{DAFTAR PUSTAKA}

Al-Qur'an dan Terjemahannya, Madinah al Munawwarah, t.p., 1412 
Dodge, Bayad, Muslim Education in Medieval Times, Washington D.C. : The Midle East Institue, 1992.

Gibb, H.A.R, Mohammedanism, London: Oxford University Press, Paperback, 1969.

Gibb, H.A.R, (Ed.), Encyclopedia of Islam, New Edition, Volume I, Leiden: t.p., 1960.

Hasan Ibrahim Hasan, Sejarah dan Kebudayaan Islam, terj. Djahdan Humam, cet. ke-1; Yogyakarta: Kota Kembang, 1889.

Hitti, Philip K. History of the Arab from the Earliest Times to the Present, Ninth Edition; New York: St. Martin's Press, 1968.

Hitti, Philip K., Dunia Arab Sajarah Ringkas, terj. Ushuluddin Hutagalung dan ODP. Sihombing, cet. ke-7; Bandung: Sumur Bandung, t. th.

Nakosteen, Mehdi, Kontribusi Islam atas Dunia Intelektual Barat, Deskripsi Analisis Abad Keemasan Islam, terj. Joko S. Kahhar \& Supriyanto Abdullah, cet. ke-1; Surabaya : Rislah Gusti, 1996.

Madjid, Nurcholish, Khazanah Intelektual Islam, cet. ke-2; Jakarta: Bulan Bintang, 1984.

Shiddiqi, Nourouzzaman, Tamaddun Muslim Bunga Rampai Kebudayaan Islam cet. ke-1; Jakarta: Bulan Bintang, 1986.

Shiddiqi, Nourouzzaman, Pengantar Sejarah Muslim, cet. ke-1; t.tp.: Nur Cahya, 1983.

Shiddiqi, Nourouzzaman, Jeram-Jeram Peradaban Muslim, cet. ke-1; Yogyakarta: Pustaka Bintang, 1996.

Shihab, M. Quraish, Wawasan Al- Qur'an, cet. ke-3; Bandung: Mizan, 1996.

Syalabi, Ahmad, Tarikh al Tarbiyah al-Islamiyah, terj. penulisnya ke bahasa Inggris History of Muslim Education, dan ke bahasa Indonesia Sejarah Pendidikan Islam terj. Mochtar Jahja dan M. Sanusi Latif Jakarta : Bulan Bintang, t.th.

Stanton, Charles Michael, Pendidikan Tinggi dalam Islam Sejarah dan Peranannya dalam Kemajuan Ilmu Pengetahuan, terj. Afandi dan Hasan Asari, cet. ke-1, Jakarta : Logos Publishing House, 1994.

Tim Penulis IAIN Syarif Hidayutullah, Ensiklopedi Islam Indonesia, Jakarta: Djambatan, t.th.

Watt, Montgomery, Kejayaan Islam : Kajian Kritis dari Tokoh Orientalis, terj. Hartono Hadikusumo, Yogyakarta: Tiara Wacana, 1990. 